\title{
NEWBORNS WITH A POSITIVE SARS-COV-2 TEST IN THE PERIPARTUM PERIOD. ARE THEY REALLY INFECTED?
}

\author{
André Coelho Almeida ${ }^{1}$, Maria João Vieira². \\ ${ }^{1}$ Department of Pediatrics and Neonatology, Central Hospital of Trás-Os Montes and Alto Douro, Portugal; \\ ${ }^{2}$ Department of Neonatology, Senhora da Oliveira Hospital, Portugal.
}

\section{KEYWORDS}

Newborn, SARS-CoV-2, False positives, Peripartum.

\author{
ARTICLE HISTORY \\ Received 11 December 2020 \\ Accepted 5 February 2021
}

Incidence of SARS-CoV-2 infection is difficult to estimate in newborns due to difficulty in determining the timing of the occurrence. Although some evidence may be favorable to the existence of vertical transmission, a first positive test in the newborn can mean viral replication or just contamination during passage through the vaginal canal or from the environment. ${ }^{1}$ The World Health Organization has issued recommendations on the diagnosis of intrauterine Sars-CoV-2 infection which is based on the following three key conditions: evidence of maternal infection during pregnancy, in utero fetal Sars-CoV-2 exposure (positive placental or $<24 \mathrm{~h}$ of life newborn RT-PCR or newborn IgM/IgA), and confirmation of viral persistence or immune response in the neonate (positive RT-PCR in a newborn's sterile sample at 2448 h of life). ${ }^{2}$ Upper respiratory tract secretions are not sterile. In our experience, with 94 deliveries of pregnant women who had SARS-CoV-2 during pregnancy, between February 2020 to February 2021, we found 2 newborns with a $1^{\text {st }}$ positive test (SARS-CoV-2 RT-PCR from upper airway sample, collected $<24$ h of life), but with $2^{\text {nd }}$ negative result collected between $24-48 \mathrm{~h}$ of life (upper respiratory tract RT-PCR and serology). Both newborns were asymptomatic suggestive of false positives, probably due to contamination during vaginal canal. It is recommended to bathe newborns after birth to try to remove virus remains which can be present in newborn nose or skin surface. ${ }^{3}$ Although breastfeeding was initially contraindicated in mothers with SARSCoV-2 infection, with the evolution of knowledge, we already know that it is possible for a mother to breastfeed and share the same room, as long as the mother maintains hygiene measures and use of a mask because transmission is more likely from respiratory secretions and less likely from breast milk. ${ }^{3}$ The testing time is not consensual and there are differences in the recommendations between societies. Center for Disease Control and Prevention ${ }^{4}$ regardless of the presence of maternal symptoms suggest doing a SARS-CoV-2 test at 24 hours of life with repetition at $48 \mathrm{~h}$ of life, if the

Address for Correspondance: André Coelho Almeida, Centro Hospitalar de Trás-Os-Montes e Alto Douro, R. dos Lagoeiros no 43, 5000 Vila Real, Portugal.

Email: andrec_almeida@hotmail.com first test is negative, similar to American Academy of Pediatrics (AAP). ${ }^{3}$ In contrast the Spanish Society of Neonatology proposes the hypothesis of testing before $24 \mathrm{~h}$ of life and after $48 \mathrm{~h} .{ }^{5}$ In case the newborn first test is positive it is recommended to obtain a new test, between 24-48h of life, and serologies (IgM) to confirm the vertical infection or, in case of both negative, confirm that it is a false positive.

Thus, one should be aware of false positive SARSCoV-2 RT PCR in newborns born to infected mothers and further testing with repeat PCR and serology at 48 hours is recommended.

\section{Compliance with Ethical Standards \\ Funding: None \\ Conflict of Interest: None}

\section{References}

1. Tolu LB, Ezeh A, Feyissa GT. Vertical transmission of Severe Acute Respiratory Syndrome Coronavirus 2: A scoping review. PLoS One. 2021;16:e0250196.

2. World Health Organization (WHO). Definition and categorization of the timing of mother-to-child transmission of SARS-CoV-2: scientific brief, February 2021. Available at URL: https://apps.who.int/iris/handle/10665/339422. Accessed on 25th July 2021.

3. American Academy of Pediatrics. FAQs: Management of Infants Born to Mothers with Suspected or Confirmed COVID-19. Available at URL: https://services.aap.org/ en/pages/2019-novel-coronavirus-covid-19-infections/ clinical-guidance/faqs-management-of-infants-born-tocovid-19-mothers/. Accessed on 25th July 2021.

4. Centers for disease control and prevention. Evaluation and Management Considerations for Neonates At Risk for COVID-19. Available at URL: https://www.cdc.gov/ coronavirus/2019-ncov/hcp/caring-for-newborns.html. Accessed on 25th Juy 2021.

5. Sociedad Española de Neonatologia. Recomendaciones para el manejo del recién-nacido en relación com la infección por SARS-COV-2. Available from URL: https:// www.aeped.es/sites/default/files/recomendaciones_ seneo_sars-cov-2_version_6.2_27052020_.pdf. Accessed on 25th July 2021. 